\title{
The Importance of Antiviral Prophylaxis against Hepatitis $B$ Virus in Patients under Immunosuppressive Therapy
}

\author{
Immünosupresif Tedavi Alan Hastalarda Hepatit B Virus Profilaksisinin Önemi
}

\author{
๑ Firdevs Aksoy, ๑ Selçuk Kaya, ๑ Hanife Nur Karakoç, ๑ Gürdal Yılmaz, @ Serhat Atalar, ๑ Iftihar Köksal
}

Karadeniz Technical University Faculty of Medicine, Department of Infectious Diseases and Clinical Microbiology, Trabzon, Turkey

\begin{abstract}
Objectives: Immunosuppressive (IS) therapies present a risk of reactivation in patients with previous or known hepatitis $B$ virus (HBV) infection and may cause mortality and morbidity. Before starting these therapies, patients should be tested for HBV serology and evaluated for antiviral therapy.

Materials and Methods: hepatitis B surface antigen (HBsAg)positive or HBsAg-negative and Anti-HBs and/or anti-HBc immunoglobulin-positive patients aged over 18 years old who were scheduled to undergo or who were already on IS therapy due to underlying diseases were evaluated retrospectively. The study included patients who had monthly transaminase levels during the first six months of antiviral prophylaxis, and then who had transaminase and HBV-DNA levels every three months during subsequent follow-ups.

Results: Sixty-three patients were included in the study. Fortyeight patients $(76 \%)$ received prophylaxis with IS therapy and 15 patients $(24 \%)$ did not receive prophylaxis at the appropriate time. $\mathrm{HBV}$ reactivation $(\mathrm{HBV} r)$ was observed in three patients who did not receive prophylaxis at the appropriate time. The incidence of $\mathrm{HBV}$ in all our patients was $4.8 \%$, but was $20 \%$ in patients with delayed prophylaxis.

Conclusion: IS therapies represent a major risk in terms of HBVr. Before starting these therapies, patients should be evaluated for antiviral prophylaxis by testing their HBV serology.

Keywords: Hepatitis B virus, prophylaxis, immunosuppressive therapy
\end{abstract}

ÖZ

Amaç: Immünosupresif tedaviler, önceki veya bilinen hepatit B virüsü (HBV) enfeksiyonu olan hastalarda reaktivasyon açısından bir risk oluşturur ve mortalite ve morbiditeye neden olabilir. Bu tedavilere başlamadan önce, hastalar HBV serolojileri test edilerek antiviral tedavi açısından değerlendirilmelidir.

Gereç ve Yöntemler: Altta yatan hastalıklar nedeniyle immünosupresif tedavi planlanan veya daha önce başlanan 18 yaş üstü hepatit B yüzey antijeni (HBsAg)-pozitif veya HBsAg-negatif ve anti-HBs ve/veya anti-HBc immünoglobulin-pozitif hastalar retrospektif olarak değerlendirildi. Çalışmaya antiviral proflaksi başlanan hastalardan ilk 6 ay boyunca aylık transaminaz, sonraki takiplerinde her üç ayda bir transaminaz ve HBV-DNA seviyeleri bakılan hastalar dahil edildi.

Bulgular: Altmış üç hasta çalışmaya alındı. Kırk sekiz (\% 76) hastaya immünosupresif tedavi ile birlikte profilaksi başlandı, 15 (\%24) hastada profilaksi uygun zamanda başlanmadı. Uygun zamanda profilaksi alamayan hastaların üçünde HBV reaktivasyonu (HBVr) görüldü. Tüm hastalarımızda $\mathrm{HBVr}$ insidansı \%4,8 idi, ancak gecikmiş profilaksi olan hastalarda \%20 idi.

Sonuç: Immünsupresif tedaviler HBV reaktivasyonu açısından önemli bir risk oluşturmaktadır. Bu tedavilere başlamadan önce, hastalar HBV serolojilerini test ederek antiviral profilaksi açısından değerlendirilmelidir.

Anahtar Kelimeler: Hepatit B virüs, profilaksi, immünosupresif tedavi

Aksoy F, Kaya S, Karakoç HN, Yılmaz G, Atalar S, Köksal İ. The Importance of Antiviral Prophylaxis against Hepatitis B Virus in Patients under Immunosuppressive Therapy. Viral Hepat J. 2019;25:50-54. 


\section{Introduction}

Hepatitis B virus (HBV) infection is one of the world's most important health problems. Immunosuppressive (IS) therapies constitute a risk in terms of $\mathrm{HBV}$ reactivation ( $\mathrm{HBV}$ ) and can cause mortality and morbidity in patients with previous or known HBV infection (1,2). Patients receiving these must therefore first be tested in terms of HBV serology (1,2). Cancer chemotherapy, autoimmune diseases, IS therapies in patients receiving solid organ and stem cell transplantation, glucocorticoids, and biological agents frequently used in recent years are all risk factors for reactivation $(1,2,3,4,5,6)$. $\mathrm{HBVr}$ is characterized by a symptomatic or asymptomatic increase in serum aminotransferase (alanine aminotransferase or aspartate aminotransferase) levels. An increase in HBV-DNA frequently accompanies that manifestation $(1,2,3,7)$. HBVr is defined by the European Association for the Study of the Liver and the Asian Pacific Association for the Study of the Liver as hepatitis B surface antigen (HBsAg) seroreversion and an increase in HBV-DNA levels $(2,8)$. According to the American Association for the Study of Liver Diseases, active necroinflammatory disease of the liver in inactive $\mathrm{HBsAg}$ carriers or subjects with histories of HBV infection is defined as reactivation (4). $\mathrm{HBV}$ r can be prevented in subjects receiving IS therapy with antiviral prophylaxis. HBV prophylaxis should be initiated 1-3 weeks before the IS therapy, if possible, or at least concomitantly with the IS therapy $(1,2,4,7,8,9,10,11)$. However, this is known to be less effective on liver damage when given after IS therapies have already been started $(1,2,4,7,8,9,10,11)$. According to the American Gastroenterological Association (AGA) guideline, the risk of reactivation in continuing or previous HBV infection varies depending on serology and/or immunosuppression (1). Subjects such as the prevention of reactivation, the most appropriate population for screening, who should use prophylaxis, the best specific agent, duration of prophylaxis, and monitoring when prophylaxis is not employed are still unclear $(1,2)$. However, the consensus in all guidelines is that it is essential for patients to be evaluated in terms of antiviral therapy before IS therapy begins in order to prevent progression of $\mathrm{HBV} r$ and underlying disease (since IS therapy may be discontinued when $\mathrm{HBV}$ r develops) $(1,2,7,8,9,10,11)$.

The purpose of this study was to assess the effect on $\mathrm{HBV}$ development of prophylactic antiviral therapy in patients receiving IS therapy. While there have been previous case reports from Turkey, we encountered no studies concerning HBVr, and our study is thus the first of its kind from Turkey.

\section{Materials and Methods}

This study was conducted at our clinic between 01.01.2010 and 30.10.2016. The data were analyzed retrospectively. We evaluated patients diagnosed with chronic hepatitis B that received IS therapy or planned. HBsAg-positive or HBsAg-negative and anti-HBs and/or anti-HBc Immunoglobulin G (lgG)-positive patients aged over 18 age scheduled to be or already started on IS therapy due to underlying diseases (patients with solid or hematological malignity receiving chemotherapy, with autoimmune and/or rheumatological diseases, patients undergoing solid organ or stem cell transplantation, or patients using IS therapy, glucocorticoids, or biological agents for any reason) were enrolled in the study. Patients with known transaminase and HBV-DNA levels were included. Patients with human immunodeficiency virus (HIV), HCV, Delta co-infection were not included. Antiviral prophylaxis has started according to the guidelines of the period $(1,4,7)$. Risk assessment performed according to AGA guidelines (1). No additional examination was requested except for the recommendations of the guidelines in the follow-up of the patients. Data of patients were obtained from electronic records. The study included patients who had received antiviral prophylaxis for the first 6 months of transaminase monthly, followed by transaminase and HBV-DNA levels every three months. One of lamivudine, tenofovir and entecavir was used as antiviral. Patients were divided into two groups. Group 1: Patients had been started on prophylaxis together with IS therapy (appropriate time), Group 2: Patients had not been started on prophylaxis timely (patients who did not receive prophylaxis at the appropriate time.). Data analysis was performed by using frequencies for the descriptive statistics.

\section{Statistical Analysis}

Data analysis was performed by using frequencies for the descriptive statistics.

\section{Results}

Sixty-three patients were included in the study, 33 men (52.3\%) and 30 women (47.6\%). Patients' mean age was $52.2 \pm 14.2$ years (24-86). HBsAg, anti-HBc lgG was positive and anti-HBs-negative in 54 patients (85.7\%). Forty-eight patients (76\%) had been started on prophylaxis together with IS therapy (group 1), while $15(24 \%)$ had not been started on prophylaxis timely (group 2). Patients' characteristics are shown in Table 1. In terms of IS drugs, $29(46.1 \%)$ patients received anti-TNF, 24 (38.1\%) chemotherapy, 5 (\% 7.9) took steroids, and 5 (7.9\%) received chemotherapy combined with steroids. Based on the AGA guideline (1). In all groups, prophylaxis was evaluated by considering IS risk group, HBV serology and underlying diseases (1).

$27(42.9 \%)$ of the patients were in the high risk group, 31 $(49.2 \%)$ were in the moderate risk group and 5 (7.9\%) were in the low risk group. Of the high-risk patients, 18 (66.7\%) received chemotherapy, 3 (11.1\%) received anti-TNF, 3 (11.1\%) received steroid and $3(11.1 \%)$ received steroid and chemotherapy. In twenty-seven (100\%) patients were HBsAg positive/anti-HBc IgG positive of these 26 (96.3\%) were HBeAg negative and 1 (3.7\%) was $\mathrm{HBeAg}$ positive. Eighteen (66.7\%) lamivudine, 7 (25.9\%) tenofovir and 2 (7.4\%) entecavir were used as antiviral prophylaxis in high risk patients. HBV-DNA levels were $<2000 \mathrm{IU} / \mathrm{mL}$ in 15 (55.6\%) patients and HBV-DNA >2000 $\mathrm{IU} / \mathrm{mL}$ in 12 (44.45) patients. $86.2 \%$ of the patients receiving anti- tumor necrosis factor (TNF) were moderate risk, $10.3 \%$ were high risk, and 3.5\% were low risk.

Lamivudine, tenofovir and entecavir were used as prophylactic therapy by 46 (73\%), 11 (17.4\%) and 6 (9.5\%) patients, respectively. Eight patients $(72.7 \%)$ receiving tenofovir had experience of lamivudine.

The underlying diseases of $\mathrm{HBeAg}$ negative patients were rheumatological disease $(n=38)$, hematological malignity $(n=14)$, solid tumor $(n=2)$, renal transplantation $(n=1)$ and bone marrow transplantation $(n=1)$. The prophylactic therapies of $\mathrm{HBeAg}$ 


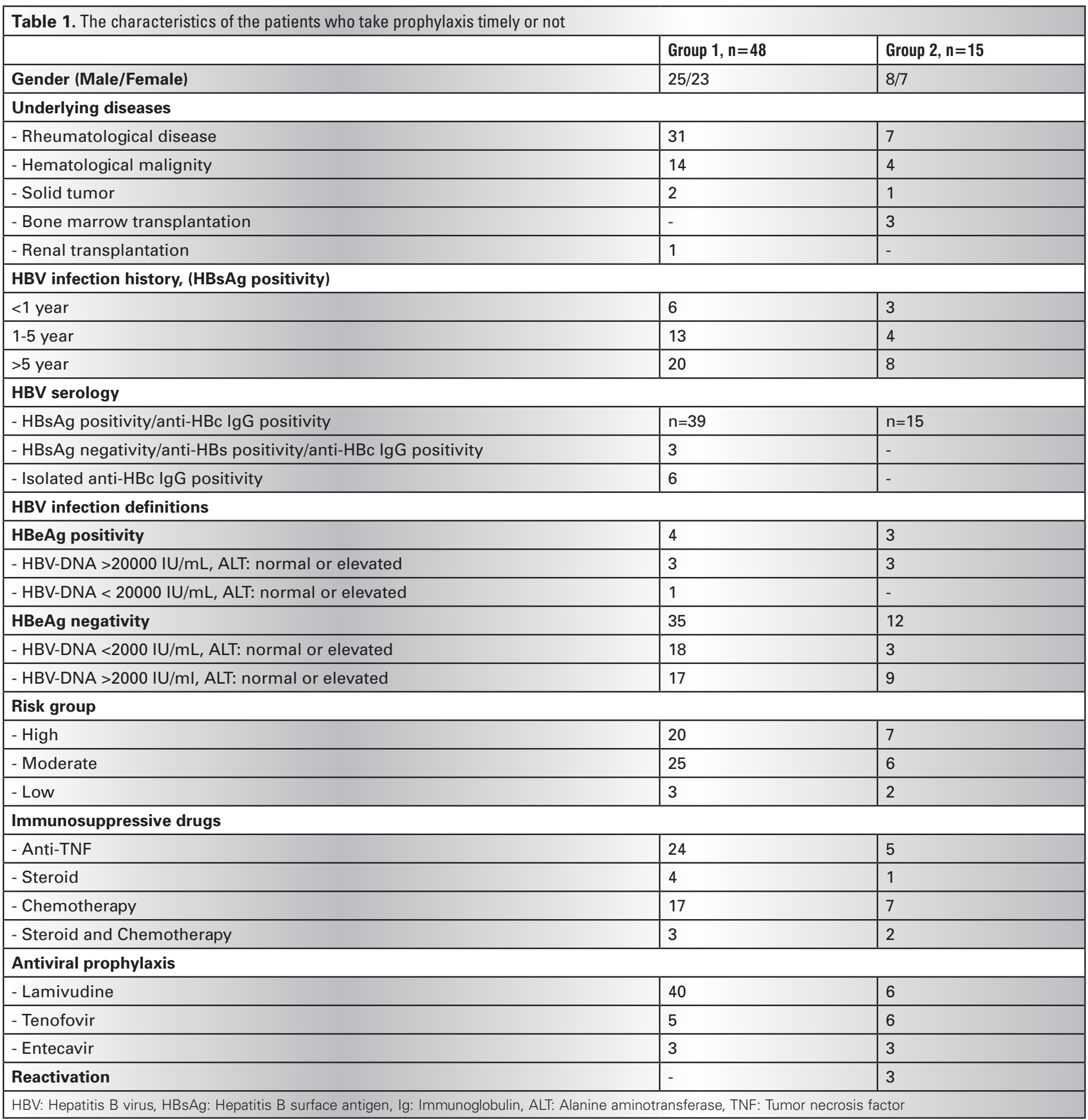

negative patients were lamivudine $(n=42)$, tenofovir $(n=8)$ and entecavir $(n=6)$. The underlying diseases of $\mathrm{HBeAg}$ positive patients were hematological malignity $(n=4)$, solid tumor $(n=1)$ and bone marrow transplantation $(n=2)$. The prophylactic therapies of $\mathrm{HBeAg}$ positive patients were lamivudine $(n=4)$ and tenofovir $(n=3)$. The underlying diseases of isolated anti-HBc lgG positive patients were hematological malignity $(n=3)$, rheumatological disease $(n=2)$ and bone marrow transplantation $(n=1)$. The prophylactic therapies of isolated anti-HBc lgG positive patients were lamivudine $(n=4)$, entecavir $(n=1)$ and tenofovir $(n=1)$.
The $\mathrm{HBV}$ r rate among all our patients was $4.8 \%$, but the figure was $20 \%$ among patients in whom prophylaxis was delayed. The rate among the $54 \mathrm{HBsAg-positive} \mathrm{patients} \mathrm{was} \mathrm{5.6 \% .} \mathrm{Delay} \mathrm{time}$ of prophylaxis was $9.5 \pm 9.2 /$ month. The time of referral of the patients in group 2 from the clinics treating the underlying disease to our clinic was long. It was thought that this was due to the lack of awareness of the relevant clinics about HBVr. Three of the patients (4.8\%) not receiving prophylaxis after being started on IS therapy presented with a manifestation of HBVr. All three patients who developed $\mathrm{HBV}$ r were male. IS treatment and underlying disease of 


\begin{tabular}{|c|c|c|c|}
\hline & Patient 1 & Patient 2 & Patient 3 (Exitus) \\
\hline Age & 25 & 36 & 76 \\
\hline Underlying diseases & Rheumatological disease & Rheumatological disease & Hematological malignity \\
\hline $\begin{array}{l}\text { HBV infection history } \\
\text { (HBsAg positivity) }\end{array}$ & $<1$ year & $<1$ year & $>5$ year \\
\hline & Anti-HBs negative & Anti-HBs negative & Anti-HBs negative \\
\hline & HBeAg negative & HBeAg negative & HBeAg negative \\
\hline & Anti-HBc IgG positivity & Anti-HBc IgG positivity & Anti-HBc IgG positivity \\
\hline $\begin{array}{l}\text { HBV-DNA level (when admitted to } \\
\text { hospital) }\end{array}$ & $1.07 \times 10^{3} \mathrm{IU} / \mathrm{mL}$ & $1.07 \times 10^{5} \mathrm{IU} / \mathrm{mL}$ & $3.89 \times 10^{7} \mathrm{IU} / \mathrm{mL}$ \\
\hline Risk group (AGA guideline) & Moderate & High & Low \\
\hline Prophylactic agents & Lamivudine & Entecavir & Lamivudine \\
\hline $\begin{array}{l}\text { Delay time of prophylaxis } \\
\text { (HBVr time) }\end{array}$ & $10 /$ month & 4/ month & 30/ month \\
\hline
\end{tabular}

HBVr: Hepatitis B Virus reactivation, HBsAg: Hepatitis B surface antigen, Ig: Immunoglobulin, AGA: American Gastroenterological Association, HBV: Hepatitis B Virus

the patients were showed in the Table 2. Patient 3 did not receive antiviral prophylaxis during previous IS therapy. The patient received chemotherapy one month before he came to us. When the patient was admitted to the service, Lamivudine prophylaxis was started (because the patient developed respiratory distress and the patient started high-dose steroid therapy). Transaminase levels and HBVDNA level were increased. HBVr was considered in the patient. Patient 3 died in intensive care unit on the $50^{\text {th }}$ day of hospitalization from fulminant hepatitis $\left(50^{\text {th }}\right.$ Day of Antiviral Prophylaxis). The characteristics of the patients who developed HBVr were shown in the Table 2.

Fifty $(79.3 \%)$ continued with prophylactic therapy at six-month follow-up. HBV-DNA exceeded $2000 \mathrm{lU} / \mathrm{mL}$ in three patients at the end of six months. IS therapy was continuing in two of these patients. Patients had non-compliance to prophylactic therapy. When prophylactic therapy compliance is achieved, the three patients' HBV-DNA became negative at the end of the $12^{\text {th }}$ month. Two of the patients had used lamivudine and one had tenofovir.

The HBV-DNA levels of two patients with negative HBV-DNA at six months rose above $2000 \mathrm{IU} / \mathrm{mL}$ at the end of 12 months. Both patients were taking lamivudine. Flare-up occurred at the end of 12 months in one patient not using treatment regularly. While no concrete cause could be identified in the other patient, resistance tests could not be performed in the patients. All the other patients were persisted with HBV-DNA negativity.

\section{Conclusion}

Individuals encountering $\mathrm{HBV}$ infection are at risk of $\mathrm{HBVr}$ when their immunity is suppressed. HBVr may appear with differing clinical manifestations, from asymptomatic disease to a severe and fatal course. This also affects the morbidity and mortality of the underlying disease as a cause of discontinuation of immunosuppression and chemotherapy (11).

Determining serological status and type and duration of immunosuppression by screening patients at risk of reactivation is very important in the management of the antiviral therapy process $(1,2,4,7,8,9,10)$. Patients receiving IS therapy must be scanned in terms of $\mathrm{HBsAg}$, anti-HBs and anti-HBc markers before treatment. In terms of our patients' serological parameters, $\mathrm{HBsAg}$, Anti-HBs and anti-HBc lgG positivity rates were $89.4 \%$, $1.8 \%$, and $100 \%$, respectively. $\mathrm{HBV}$ is more common in patients with HBsAg positivity $(1,2,3,4,5,6,7,8,9)$. Tavakolpour et al. (3) reported a high risk of reactivation in $\mathrm{HBsAg}$ - and $\mathrm{HbeAg}$-positive patients. Our three patients with reactivation were $\mathrm{HBsAg-positive}$ and $\mathrm{HBeAg-negative.} \mathrm{Lee} \mathrm{et} \mathrm{al.} \mathrm{(12)} \mathrm{reported} \mathrm{a} 12.3 \%$ level of $\mathrm{HBVr}$ in $122 \mathrm{HBsAg-positive} \mathrm{patients} \mathrm{receiving} \mathrm{IS} \mathrm{therapy} \mathrm{due}$ to rheumatological diseases, compared to $5.6 \%$ in our study. No previous studies from Turkey, including case reports, have reported this rate.

The type of IS employed and length of use also constitute a risk for reactivation $(1,2,3,4,5,6,7,8,9)$. When drugs that suppress $\mathrm{B}$ cells, antracycline derivatives and high-dose corticosteroids are used, the risk of reactivation is above $10 \%$. The risk of reactivation with the use of TNF-alpha, cytokine, integrin, tyrosine kinase inhibitors and low-dose corticosteroids ranges between $1 \%$ and $10 \%$. The reactivation risk associated with low-dose or intra-articular corticosteroid or conventional IS drug (azathioprine, 6-merkaptopurin, and methotrexate) use is less than $1 \%(1,11)$. In our study, $46.1 \%(n=29)$ of patients had received anti-TNF, $38.1 \%$ chemotherapy, $7.9 \%$ steroids, and $7.9 \%$ chemotherapy and steroid therapy. According to the AGA guideline (1), $86.2 \%$ of our patients receiving anti-TNF were at moderate risk, and the most commonly used agent was infliximab $(n=13)$. An additional $10.3 \%$ 
were at high risk, and all had used rituximab, while 3.5\% were in the low-risk group. Two of the patients with $\mathrm{HBV}$ r had used antiTNF (infliximab, and rituximab), and the other patient, azathioprine. The IS therapies used by our patients were in the low-, moderate-, and high-risk groups. Although azathioprine involves a low risk $(<1 \%$ risk of $\mathrm{HBVr}), \mathrm{HBV}$ r occurred in one of our patients, and that patient died. One previous study reported that a risk of $\mathrm{HBVr}$ with azathioprine, but that this was lower compared to other chemotherapeutic agents (13)

The current antivirals of choice in patients receiving IS therapy are tenofovir and entecavir $(11,14)$. Lamivudine therapy was administered to patients with $\mathrm{HBV}$ r receiving anti-TNF, and entecavir therapy to a patient using azathioprine.

IS therapies, steroids, and biological agents that have become intensively used in several diseases in recent years constitute a major risk in terms of $\mathrm{HBV}$, and these cases may be missed in clinical practice. These patients must be evaluated in terms of prophylaxis requirement by means of serological screening before treatment. Prophylactic antiviral therapy prevents HBVr in patients receiving IS therapy, but as seen in our study, delayed treatment can result in morbidity and mortality. $\mathrm{HBV}$ r was present in one patient in our low-risk group, and it is impossible to say whether this was associated with the natural course of the disease or else incidental, and further studies involving larger patient numbers on this subject are now needed. It should be remembered that $\mathrm{HBVr}$ can also be seen in low-risk patients, and we think that these patients also require close and careful follow-up.

\section{Ethics}

Ethics Committee Approval: Retrospective study.

Informed Consent: Retrospective study.

Peer-review: External and internal peer-reviewed.

\section{Authorship Contributions}

Surgical and Medical Practices: F.A., S.K., Concept: F.A., Design: F.A., S.K., Data Collection or Processing: F.A., H.N.K., S.A., I.K., G.Y., Analysis or Interpretation: F.A., G.Y., Literature Search: S.K., H.N.K., Writing F.A.

Conflict of Interest: The authors declare no conflict of interest.

Financial Disclosure: The authors declare that this study has not received any financial support.

\section{References}

1. Reddy KR, Beavers KL, Hammond SP, Lim JK, Falck-Ytter $\mathrm{YT}$; American Gastroenterological Association Institute. American Gastroenterological Association Institute. American
Gastroenterological Association Institute guideline on the prevention and treatment of hepatitis B virus reactivation during IS drug therapy. Gastroenterology. 2015;148:215-219.

2. European Association for the Study of the Liver. Electronic address: easloffice@easloffice.eu; European Association for the Study of the Liver. EASL 2017 Clinical Practice Guidelines on the management of hepatitis B virus infection. J Hepatol. 2017;67:370-398.

3. Tavakolpour S, Alavian SM, Sali S. Hepatitis B reactivation during IS therapy or cancer chemotherapy, management, and prevention: A comprehensive review-Screened. Hepat Mon. 2016;26:16:e35810

4. Terrault NA, Bzowej NH, Chang KM, Hwang JP, Jonas MM, Murad $\mathrm{MH}$. American Association for the Study of Liver Diseases. AASLD Guidelines for Treatment of Chronic Hepatitis B. Hepatology. 2016;63:261-283.

5. Sagnelli E, Pisaturo M, Martini S, Filippini P, Sagnelli C, Coppola $N$. Clinical impact of occult hepatitis $B$ virus infection in immunosuppressed patients. World J Hepatol. 2014;6:384-93.

6. Bessone F, Dirchwolf M. Management of hepatitis B reactivation in immunosuppressed patients: An update on current recommendations. World J Hepatol. 2016;8:385-394.

7. Karadağ Ö, Kaşifoğlu T, Özer B, Kaymakoğlu S, Kuş Y, Inanç M, Keser G, Kiraz S. Romatolojik hastalarda biyolojik ilaç kullanımı öncesi (viral) hepatit tarama kılavuzu. RAED Dergisi. 2015;7:28-32.

8. Sarin SK, Kumar M, Lau GK, Abbas Z, Chan HL, Chen CJ, Chen DS, Chen HL, Chen PJ, Chien RN, Dokmeci AK, Gane E, Hou JL, Jafri W, Jia J, Kim JH, Lai CL, Lee HC, Lim SG, Liu CJ, Locarnini S, Al Mahtab M, Mohamed R, Omata M, Park J, Piratvisuth T, Sharma BC, Sollano J, Wang FS, Wei L, Yuen MF, Zheng SS, Kao $\mathrm{JH}$. Asian-Pacific clinical practice guidelines on the management of hepatitis B: a 2015 update. Hepatol Int. 2016;10:1-98.

9. Köksal I. Immunosuppressive therapy and hepatitis B virus reactivation. Viral Hepat J. 2016;22:69-73.

10. Zeuzem S. Patients at Risk for Hepatitis B Virus Reactivation Hepatitis B Management in Special Populations. In Practice. 2016.

11. Aygen B, Demir AM, Gümüș M, Karabay $O$, Kaymakoğlu S, Köksal AŞ, Köksal I, Örmeci N, Tabak F. Immunosuppressive therapy and the risk of hepatitis $B$ reactivation: Consensus report. Turk J Gastroenterol. 2018;29:259-269.

12. Lee $\mathrm{YH}$, Bae SC, Song GG. Hepatitis B virus reactivation in HBsAg-positive patients with rheumatic diseases undergoing anti-tumor necrosis factor therapy or DMARDs. Int J Rheum Dis. 2013; 16:527-531

13. Manzano-Alonso ML, Castellano-Tortajada G. Reactivation of hepatitis B virus infection after cytotoxic chemotherapy or immunosuppressive therapy. World J Gastroenterol. 2011;17:15311537.

14. Idilman R. Management of special patient groups with hepatitis B virus infection: The EASL 2017 Clinical Practice Guidelines. Turk J Gastroenterol.2017;28:518-521. 